\title{
PRELIMINARY STUDY OF THE FAVORABILITY FOR URANIUM IN THE MADERA LIMESTONE, AND CUTLER AND CHINLE FORMATIONS OF THE SIERRA NACIMIENTO-JEMEZ MOUNTAINS AREA, NEW MEXICO
}

BENDIX FIELD ENGINEERING CORPORATION

Grand Junction Operations

Grand Junction, Colorado 81501

January 1978

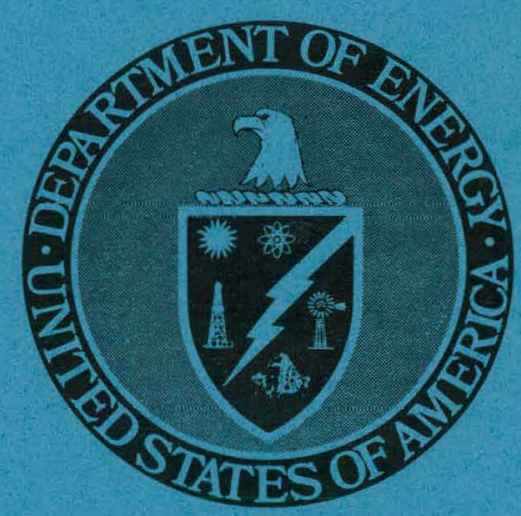

ISSUED BY THE U.S. DEPARTMENT OF ENERGY GRAND JUNCTION OFFICE UNDER CONTRACT NO. E(05-1)-1664 


\section{DISCLAIMER}

This report was prepared as an account of work sponsored by an agency of the United States Government. Neither the United States Government nor any agency Thereof, nor any of their employees, makes any warranty, express or implied, or assumes any legal liability or responsibility for the accuracy, completeness, or usefulness of any information, apparatus, product, or process disclosed, or represents that its use would not infringe privately owned rights. Reference herein to any specific commercial product, process, or service by trade name, trademark, manufacturer, or otherwise does not necessarily constitute or imply its endorsement, recommendation, or favoring by the United States Government or any agency thereof. The views and opinions of authors expressed herein do not necessarily state or reflect those of the United States Government or any agency thereof. 


\section{DISCLAIMER}

Portions of this document may be illegible in electronic image products. Images are produced from the best available original document. 
This report was prepared as an account of work sponsored by the United States Government. Neither the United States nor the United States Department of Energy, nor any of their employees, nor any of their contractors, subcontractors, or their employees, makes any warranty, expressed or implied, or assumes any legal liability or responsibility for the accuracy, completeness or usefuiness of any information, apparatus, product or process disclosed, or represents that its use would not infringe privately owned rights. 


\title{
PRELIMINARY STUDY OF THE FAVORABILITY FOR URANIUM IN THE MADERA LIMESTONE, AND CUTLER AND CHINLE FORMATIONS OF THE SIERRA NACIMIENTO-JEMEZ MOUNTAINS AREA, NEW MEXICO
}

H. P. Vizcaino, A. J. O'Neill, and F. E. Dotterer

\author{
BENDIX FIELD ENGINEERING CORPORATION \\ Grand Junction Operations \\ Grand Junction, Colorado 81501
}

PREPARED FOR THE U.S. ENERGY RESEARCH AND DEVELOPMENT ADMINISTRATION UNDER CONTRACT NO. EY-76-C-13-1664

ISSUED BY THE U.S. DEPARTMENT OF ENERGY, GRAND J̦UNCTION OFFICẸ 
THIS PAGE

WAS INTENTIONALLY

LEFT BLANK 
Summary ............................ 1

Introduction .......................... 2

Purpose . . . . . . . . . . . . . . . . . 2

Location . . . . . . . . . . . . . . . . . 2

Previous work ....................... 2

Geologic studies . . . . . . . . . . . . . . 2

Exploration ................... . 4

Procedures ..................... . . . . 4

Literature survey . . . . . . . . . . . . . 4

Field investigation . . . . . . . . . . . . . . . 4

Samples collected . . . . . . . . . . . . . . . 4

Analytical work . . . . . . . . . . . . . . . 6

Geology . . . . . . . . . . . . . . . . . . . 6

General .................... . . 6

Geologic history . . . . . . . . . . . . . . 6

Structure . . . . . . . . . . . . . . . . 9 9

Stratigraphy of selected rock units . . . . . . . . . 9

Madera Limestone . . . . . . . . . . . . . . 9

Lower gray limestone member . . . . . . . . 9

Upper arkosic limestone member . . . . . . . . 9

Cutler Formation . . . . . . . . . . . . . . 10

Chinle Formation . . . . . . . . . . . . 10

Agua Zarca Sandstone Member . . . . . . . 10

Unnamed sandstone member . . . . . . . . . . 11 
CONTENTS (continued)

$\underline{\text { Page }}$

Geology (continued)

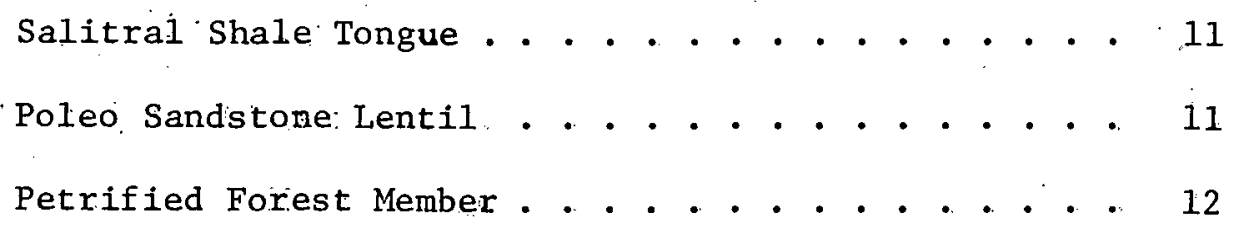

Evidence of uranium favorability . . . . . . . . . . . . 12

General . . . . . . . . . . . . . . . 12

Uranium source rocks .. . . . . . . . . . . . 12

Transmissivity . . . . . . . . . . . . . . . 12

Known uranium deposits ................. . 13

Madera Limestone . . . . . . . . . . . . . 13

Cutler Formation ................. 13

Chinle Formation . . . . . . . . . . . . 14

Results . . . . . . . . . . . . . . . . . . . 14

Conclusions . . . . . . . . . . . . . . . . . . . 14

Bibliography . . . . . . . . . . . . . . . . . . . 16 
Figure 1. Location and boundary of project area in relation to major tectonic elements of north-central New Mexico . . . . . . . . . . 3

2. Generalized stratigraphic section of the Sierra Nacimiento-Jemez Mountains area . . . . .. . . 5

Table 1. Analytical and petrographic data from rock samples . . . 7

2. Uranium analyses of ground-water samples . . . . . . . 8

Plate 1. Geologic map of the Sierra Nacimiento-Jemez Follows Mountains area . . . . . . . . . . . page 18

2.

2. Sample locations . . . . . . . . . . . . . page 18

3. Known uranium occurrences in the Madera Limestone, Cutler Formation, and Chinle Formation, Sierra Follows Nacimiento-Jemez Mountains, New Mexico....... page 18 
Sma11, surficial, secondary uranium deposits are present in several formations in the Sierra Nacimiento-Jemez Mountains region, but none of significant size are known. Field surveys indicate that the deposits are laterally discontinuous and are, in most cases, associated with carbonaceous debris. Mineral contents of as much as 0.18 percent $\mathrm{U}_{3} \mathrm{O}_{8}$ are recorded. There are 2 known deposits in the Pennsylvanian Madera Limestone, 18 in the Permian Cutler Formation, and 3 in the Triassic Chinle Formation.

The Madera Limestone consists of a lower and an upper member. The lower member is predominantly a dense limestone and is 1ithologically unfavorable. The upper member, which consists of several arkosic units interbedded with cherty limestone, is not a favorable host rock because of its thin arkosic units, the paucity of carbonaceous debris, and its lithologically unfavorable limestone.

The Cutler Formation consists mostly of interfingering siltstones and fine- to coarse-grained feldspathic and arkosic sandstones of fluvial origin. The sandstones are generally lenticular, average about $40 \mathrm{ft}$ in thickness, and are favorable. Cutler equivalents south of lat $36^{\circ} \mathrm{N}$. (Abo and. Yeso Formations) were not included in this study.

The Chinle Formation in the project area consists of five members. The Agua Zarca Member, medium-grained to conglomeratic sandstone with beds that average $30 \mathrm{ft}$ in thickness, is the only unit in the Chinle considered favorable.

The stratigraphic units under consideration have been eroded and deformed; beds dip steeply. Upturned and deeply dissected beds afford access to infiltrating waters; oxidation and flushing of pre-existing uranium deposits is therefore suspected. The uranium deposits in the Madera, Cutler, and Chinle are likely to be remnants, and the probability of locating any large deposits within the area is therefore low. There is the possibility, however, of downdip migration of uranium-hearing solutions into areas of gentle dips in the Chama and San Juan Basins, and further subsurface work is justified for the refinement of the favorability appraisal of the Cutler and Chinle in those basins: 


\section{INTRODUCTION}

This report presents the results of a preliminary favorability study of Upper Paleozoic and Triassic beds in the Sierra Nacimiento-Jemez Mountains region of north-central New Mexico. Favorability of sedimentary and volcanic rocks and of possible uranium source rocks 'was also investigated. Work was conducted from May through October 1976. The project was conducted by Bendix Field Engineering Corporation (BFEC) for the Grand Junction Office (Colorado) of the U.S. Energy Research and Development Administration (ERDA), formerly the Atomic Energy Commission (AEC).

\section{PURPOSE}

The purpose of this study was to determine the uranium favorability of the Madera Limestone (Pennsylvanian), the Cutler Formation (Permian), and the Chinle Formation (Triassic), all in the Nacimiento-Jemez Mountains area.

\section{LOCATION}

The project area comprises about 1,200 sq mi in parts of Sandoval, Rio Arriba, Taos, Santa Fe, and San Miguel Counties, New Mexico (Fig. 1). It is located within the area defined by $T$. $15 \mathrm{~N}$. through T. $23 \mathrm{~N}$. and $\mathrm{R}$. $1 \mathrm{~W}$. through R. $3 \mathrm{E}$. The region is depicted on the south-central part of U.S. Geological Survey Aztec 20 (scale 1:250,000) topographic map (no. 13-10) and the north-central part of the Albuquerque $2^{\circ}$ map (no. NI 13-1).

\section{PREVIOUS WORK}

\section{Geologic Studies}

Wood and Northrop (1946) prepared a reconnaissance geologic map of the Nacimiento and San Pedro Mountains area (P1. 1). Woodward and others (1972a, 1972b, 1973a, 1973b, 1973c, 1974a, 1974b, 1974c,1974d, 1976) made detailed geologic maps and presented a comprehensive study of the tectonic setting of the region.

Stewart and others (1972) and O'Sullivan (1974) studied the Chinle Formation of north-central New Mexico in relation Lo Trlassic strata elsewhere on the Colorado Plateall. Baars (1962) discussed the Permian stratigraphy, and Read and Wood (1947), the Pennsylvanian of the area.

Chenoweth (1974) and Hilpert (1969) summarized uranium favorability criteria applicable to the region. Hilpert assessed, in general terms, the uranium potential of formations in northwestern New Mexico. 


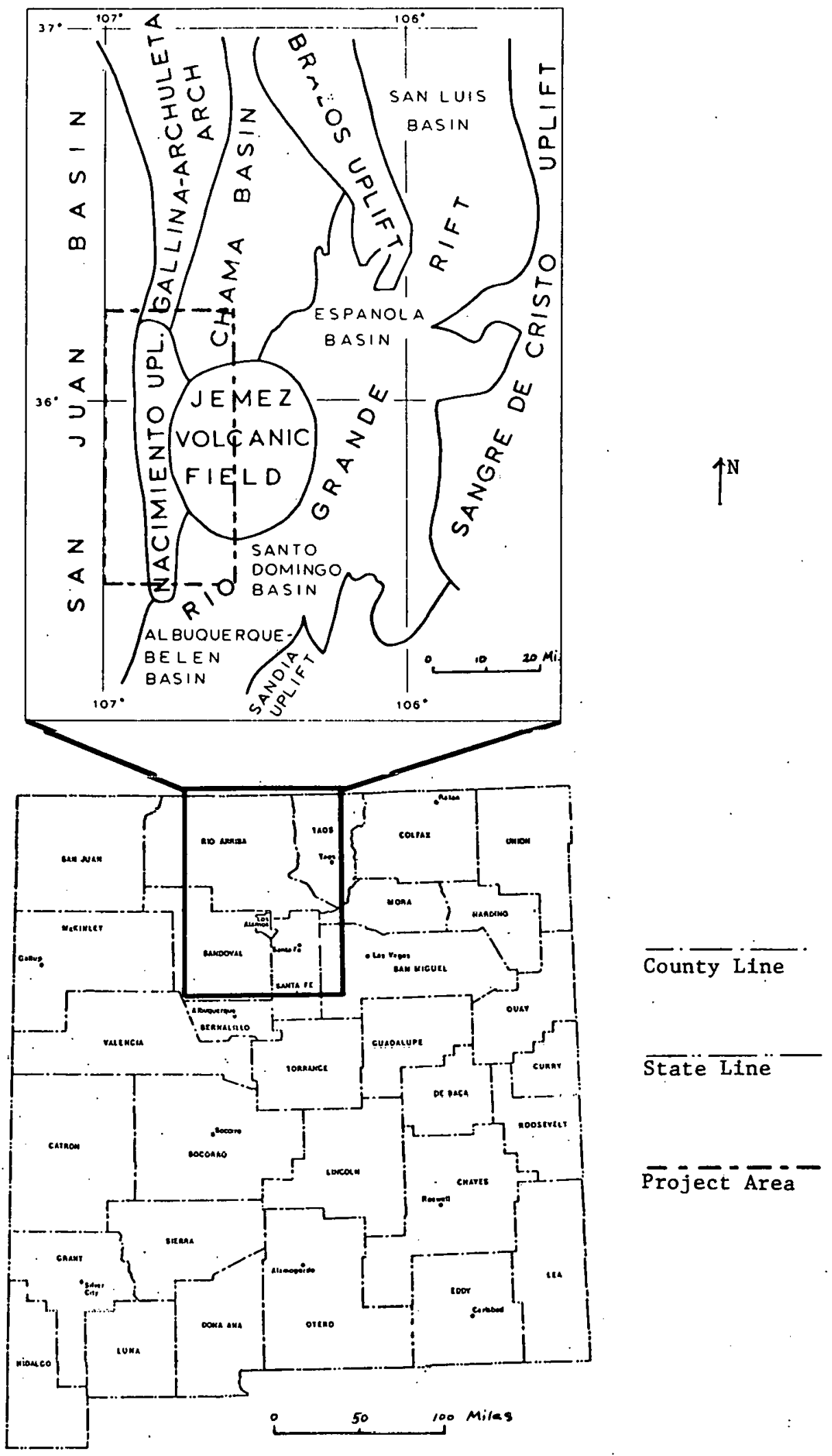

Figure 1. Location and bunidery of project area in relation to major. tectonic elements of north-central New Mexico (tectonic map after Woodward and others, 1974c). 


\section{Exploration}

Uranium deposits are known in Pennsylvanian, Permian, Triassic, Jurassic, Cretaceous, and Tertiary sedimentary and volcaniclastic rocks in the NacimientoJemez region (Fig. 2) [Chenoweth, 1974]. Despite drilling and excavation in the area, no uranium deposits with more than one ton $\mathrm{U}_{3} \mathrm{O}_{8}$ are known; only small amounts of uraniferous rock have been shipped.

The U.S. Atomic Energy Commission (AEC) and the U.S. Geological Survey (USGS) conducted air and ground scintillometer surveys over much of the Nacimiento-Jemez region. In areas where the Madera, Cutler, and Chinle are exposed, no anomalies greater than two times background were detected (Allison, 1954; Baltz, 1955; Brassfield, 1956). :Courthouse records from Rio Arriba and Sandoval Counties revealed considerable recent claim-staking activity in the region; areas exposed in the Madera Limestone and Cutler and Chinle Formations have been claimed.

\section{PROCEDURES}

\section{LITERATURE SURVEY}

Published and unpublished articles, reports, and maps were reviewed. Some information was derived from AEC open-filed reports.

\section{FIELD INVESTIGATION}

Field work consisted of locating and examining known uranium deposits and sites of published measured sections in the Madera Limestone and Cutler and Chinle Formations. Rock and ground-water samples were collected. Radiometric reconnaissance was conducted with hand-held scintillometers.

\section{SAMPLES COLLECTED}

Seventeen rock samples were collected (PL. 2): five are from knuwi uranium deposits in the Madera Limestone and Cutler and Chinle Formations, nine are from the Bandelier Tuff, and three are from Precambrian granite.

Thirty-four well and spring-water samples were collected (P1. 2). Nineteen samples represent waters flowing through sedimentary formations; fifteen samples represent waters draining possible source rocks (Precambrian granite and Bandelier Tuff). 


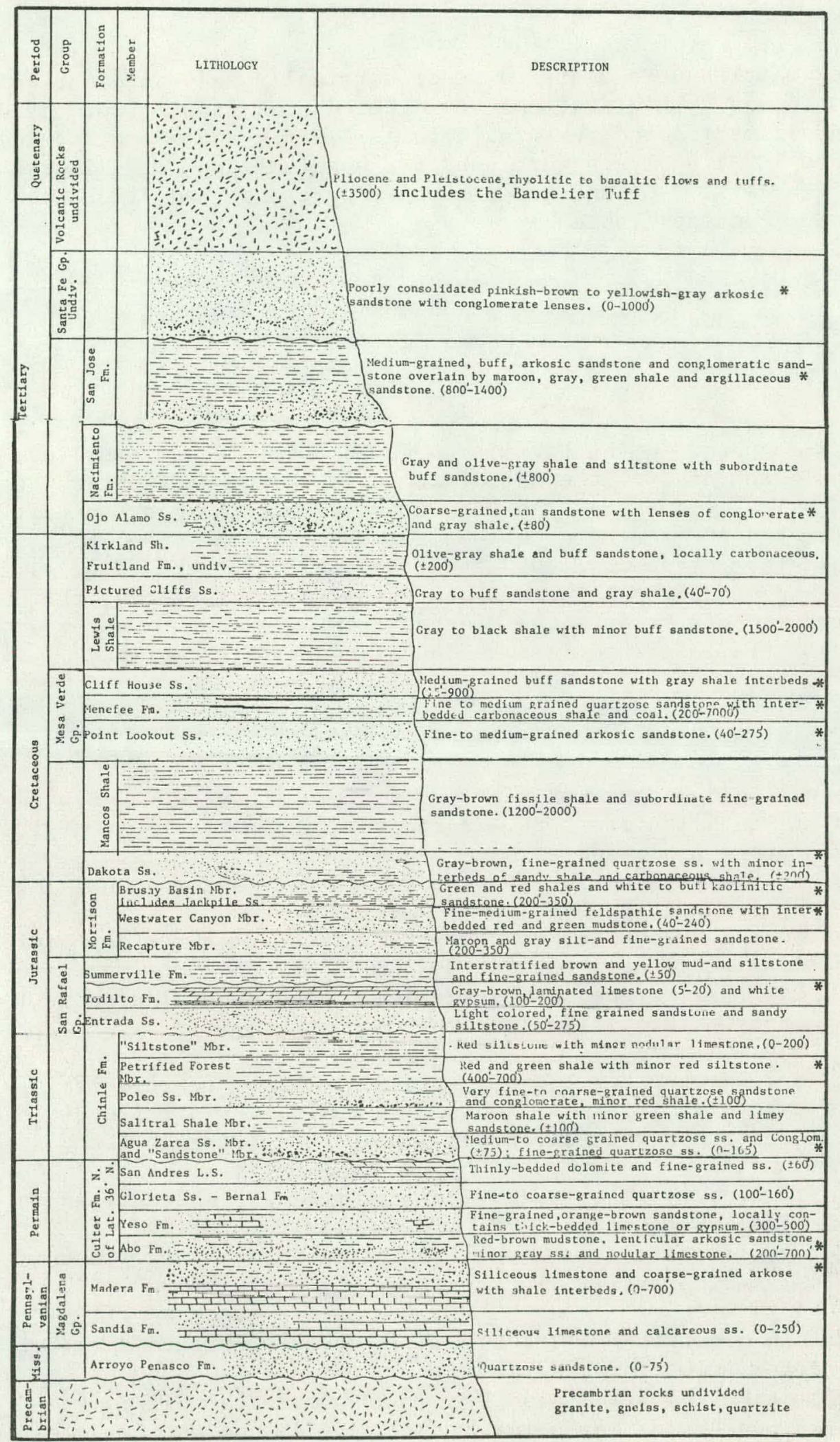

*uranium-bearing formations

Figure 2. Generalized stratigraphic section of the Sierra Nacimiento-Jemez Mountains area. 
Rock samples were analyzed fluorometrically and radiometrically for uranium content. Thin sections of selected rock samples were studied for rock classification and textural details. X-ray and scanning electron microscope (SEM) analyses were used for uranium- and clay-mineral determinations (Table 1). Ground-water samples were analyzed fluorometrically for uranium content (Table 2).

\section{GEOLOGY}

\section{GENERAL}

Rocks exposed in the Nacimiento-Jemez area are Precambrian to Quaternary in age. In the area of the Nacimiento uplift, the sedimentary section has been tectonically deformed and dips steeply into the eastern part of the San Juan Basin and the southern part of the Chama Basin. The stratigraphic column consists of about 15,000 ft of sedimentary rocks (Fig. 2). There are a number of units that contain uranium, as noted above; the three considered in this report (the Madera Limestone and the Cutler and Chinle Formations) are described in more detail under "Stratigraphy".

\section{GEOLOGIC HISTORY}

The geologic history of interest to this study, which began with the transgression of Pennsylvanian seas, is recorded in the area by marginal marine and marine limestone shale and arkosic sandstones of the Madera Limestone. Withdrawal of the Pennsylvanian seas was fnllowed by an erusiunal Interval.

Continental sedimentation characterized much of the depositional history of the Permian north of about lat $36^{\circ} \mathrm{N}$. in the project area. South of this parallel, marginal marine and marine deposition predominated during Permian time (Wood and Northrop, 1946).

A hiatus between Permian and Triassic beds is represented by a regional unconformity; Lower Triassic beds are absent. Fluvial, flood-plain, and lacustrine sediments were deposited during Late Triassic time.

After an erosional episode, Jurassic rocks were deposited in lacustrine and flood-plain environments. Extensive erosion preceded the return of seas in Late Cretaceous time. The shallow epicontinental seas deposited marine and marginal marine sediments.

Near the c'lose of Cretaceous time, increased orogenic activity produced regional deformation: The Nacimiento uplift and San Juan Basin were initiated during that time. Tertiary and Quaternary volcanism within the area, accompanied by emplacement of intrusive bodies, added abundant pyroclastic debris and further deformed the strata locally. 
TABLE 1. ANALYTICAL AND PETROGRAPHIC DATA FROM ROCK SAMPLES

\begin{tabular}{|c|c|c|c|c|c|c|}
\hline $\begin{array}{l}\text { Sample } \\
\text { no. }\end{array}$ & $\begin{array}{l}\text { Location } \\
\text { no. }\end{array}$ & Formaticn & $\mathrm{U}_{3} \mathrm{O}_{8}$ & $\mathrm{eU}_{3} \mathrm{O}_{8}$ & $\mathrm{eU} / \mathrm{U}$ & Lithologic description $* *$ \\
\hline 18827 & 1 & Cutler & $60 \mathrm{ppm}$ & -- & -- & Calcareous lithic arenite \\
\hline 18833 & 3 & Chinle & $0.15 \% *$ & - & - & Limonitic sandstone \\
\hline 19322 & 4 & Cutler & -- & -- & -- & $\begin{array}{l}\text { Arkosic arenite: andersonite } \\
\mathrm{Na}_{2} \mathrm{Ca}\left(\mathrm{UO}_{2}\right)\left(\mathrm{CO}_{2}\right)_{3} \cdot 6 \mathrm{H}_{2} \mathrm{O} \neq\end{array}$ \\
\hline 18818 & 6 & Bandelier Tuff & $9 \mathrm{ppm}$ & $15 \mathrm{ppm}$ & 1.7 & Crystal-vitric tuff \\
\hline 18820 & 7 & Bandelier Tuff & $9 \mathrm{ppm}$ & $13 \mathrm{ppm}$ & 1.4 & Crystal-vitric tuff \\
\hline 18821 & 8 & Bandelier Tuff & $4 \mathrm{ppm}$ & $13 \mathrm{ppm}$ & 3.3 & Crystal-vitric tuff \\
\hline 18822 & 9 & Bandelier Tuff & $8 \mathrm{ppm}$ & $10 \mathrm{ppm}$ & 1.3 & Crystal-vitric tuff \\
\hline 18823 & 10 & Bandelier Tuff & $9 \mathrm{ppm}$ & $12 \mathrm{ppm}$ & 1.3 & Crystal-vitric tuff \\
\hline 19695 & 15 & Precambrian granite & $6 \mathrm{ppm}$ & $8 \mathrm{ppm}$ & 1.3 & $\begin{array}{l}\text { Biotitè quartz } \\
\text { monzonite gneiss }\end{array}$ \\
\hline 19696 & 16 & Precambrian granite & $4 \mathrm{ppm}$ & 3 ppm & 0.8 & $\begin{array}{l}\text { Biotite quartz } \\
\text { monzonite gneiss }\end{array}$ \\
\hline 19697 & 17 & Precambrian granite & $3 \mathrm{ppm}$ & $3 \mathrm{ppm}$ & 1.0 & $\begin{array}{l}\text { Biotite quartz } \\
\text { monzonite gneiss }\end{array}$ \\
\hline
\end{tabular}

* $\mathrm{U}_{3} \mathrm{O}_{8}$ determined by fluorometric rethod.

$+\mathrm{eU}_{3} \mathrm{O}_{8}$ determined by $\mathrm{Mt}$. Sopris SC-132 scintillometer.

** Rock names determined by thin-section analysis:

location nos. 1 through 11 (handlens, loc. nos. 12 through 17)

* Uranium minerals identified by $\mathrm{x}$-ray analysis. 
TABLE 2. URANIUM ANALYSES OF GROUND-WATER SAMPLES.

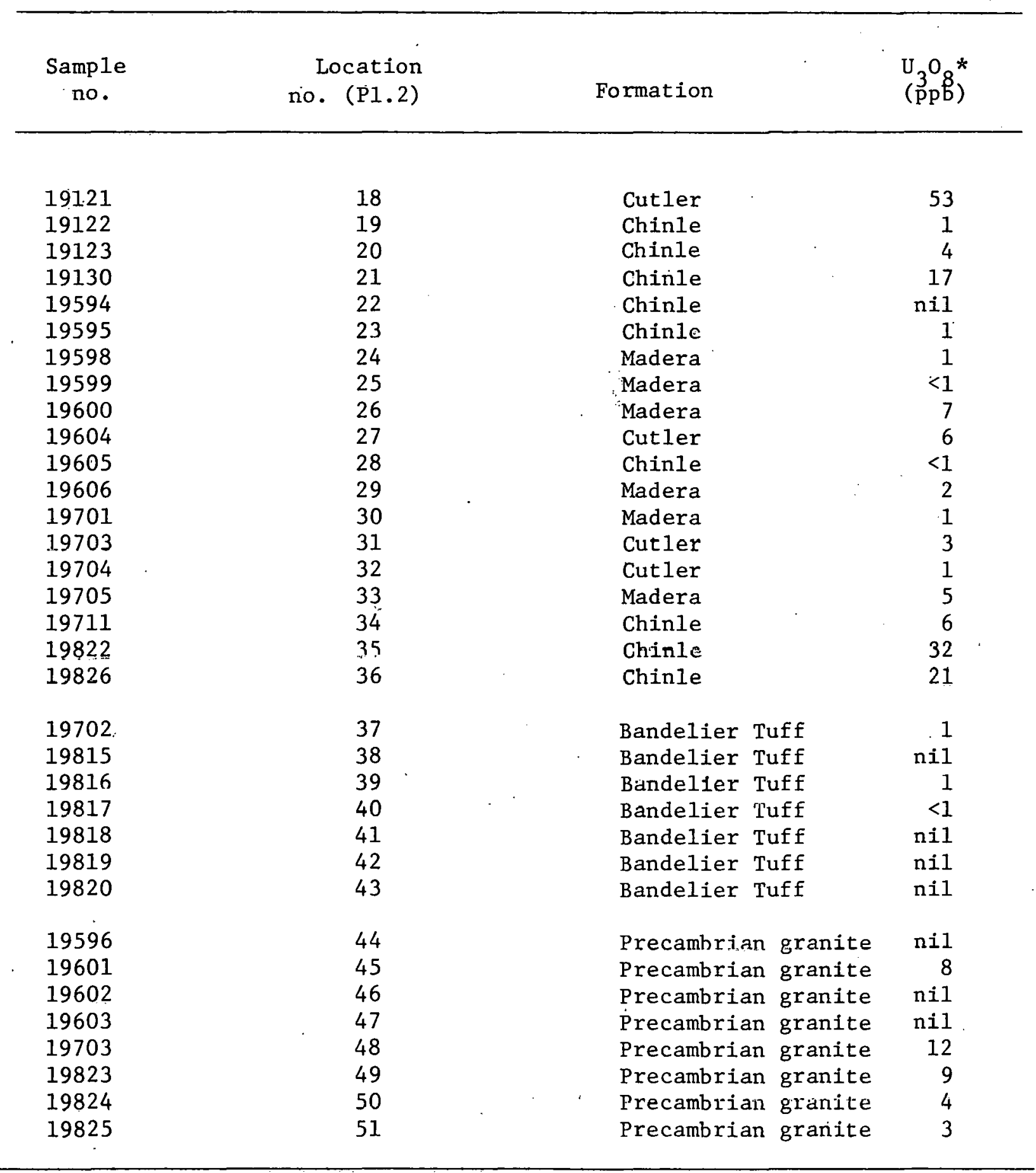

* Determined by fluorometric method. 


\section{STRUCTURE}

The project area is in three physiographic provinces: the Nacimiento uplift in the Southern Rocky Mountains Province; the San Juan and Chama Basins in the Colorado Plateau; and the Albuquerque-Belen Basin in part of the Basin and Range province (Fig. 1).

There are two major fault zones in the area (P1. 1). The northwardtrending Nacimiento-Pajarito fault, initiated during Laramide deformation, is a thrust in its northern extension in the San Pedro Mountains area and a high-angle reverse fault in the southern extension, west of the Nacimiento Mountains (Woodard and others, 1972a). Mesozoic and Paleozoic formations are. steeply upturned and overturned west of the fault. The northeasttrending Jemez-Sierrita fault is a normal fault at the western edge of the Rio Grande rift.

\section{STRATIGRAPHY OF SELECTED ROCK UNITS}

\section{Madera Limestone}

The Madera Limestone (Pennsylvanian) [Keyes, 1903] is present over much of central and north-central New Mexico. Within the study area, it crops out along the eastern and northern flanks of the Nacimiento and San Pedro Mountains (Pl. 1), where it attains a maximum thickness of $760 \mathrm{ft}$ (Duchene, 1974). The Madera consists of marine and marginal marine limestone, shale, siltstone, and sandstone and is divided into two units: a lower gray limestone member and upper arkosic limestone member (Wood and Northrop, 1946).

Lower Gray Limestone Member. The lower member consists mainly of gray, dense limestone with minor amounts of gray shale and arkosic sandstone. The unit averages about $200 \mathrm{ft}$ thick and is absent north of about 1 at $36^{\circ} \mathrm{N}$.

Upper Arkosic Limestone Member. The upper member, which averages about $300 \mathrm{ft}$ thick, is extensively exposed in the project area. It rests conformably on the lower member in the southern part of the area, but in the north, where the lower member is missing, it lies unconformably on Precambrian rocks. The upper member is overlain by Permian beds, and its upper contact is placed at the top of its uppermost limestone bed.

The member consists mainly of gray, thin- to thick-bedded limestone and minor amounts of shale and sandstone. The sandstone beds are arkosic, and the proportion of arkose increases upward in the section (Duchene, 1974). The amount of arkosic beds is as much as 5 percent. There are 1 to 4 arkosc beds, ranging from 5 to $10 \mathrm{ft}$ thick. They are gray and tan, coarse grained, poorly sorted, cross-bedded, and lenticular. Minor amounts of organic. material, including petroliferous residues and plant debris, are present locally. 
Although no detailed provenance studies are known, the ancient Peñasco axis (ancestral Nacimiento Mountains) and the Uncompahgre highlands have been proposed as possible source areas (Duchene, 1974; Read and Wood, 1947); both terrains were in part granitic.

\section{Cutler Formation}

The Cutler Formation (Early Permian) [Cross and Howe, 1905] is present in the project area north of about lat $36^{\circ} \mathrm{N}$. (Wood and Northrop, 1946). South of lat $36^{\circ} \mathrm{N}$., Cutler equivalents are represented by the Abo and Yeso Formations. It is exposed mainly north, northeast, and east of San Pedro Mountain.

The Cutler is about $500 \mathrm{ft}$ thick, on the average; however, its thickness abruptly increases northward to as much as 2,500 ft north of San Pedro Mountain (Baars, 1974). Presumably, this thickening is toward its source area in the ancient Uncompahgre highlands (Baars, 1974).

The Cutler locally consists predominantly of red and gray siltstone and fine- to coarse-grained, well-sorted, cross-bedded, feldspathic to arkosic sandstone. The sandstones are generally lenticular and average $40 \mathrm{ft}$ in thickness. They contain minor amounts of carbonaceous debris.

\section{Chinle Formation}

The Chinle Formation (Late Triassic) [Gregory, 1917] extends over much of the Colorado Plateau province and over large parts of the area. It is exposed in the southern Chama Basin and north, west, south, and southeast of the Nacimiento Mountains (P.1. . 1). The Shinle is regionally unconformable with the underlying Permian and overlying Jurassic beds. Five stratigraphic units (Stewart and others, 1972), which consist of continental claystone, siltstone, sandstone, and conglomerate, are, in ascending order: Agua Zarca Sandstone Member, an unnamed sandstone member, Salitral Shale Tongue, Poleo Sandstone Lentil, and Petrified Forest Member.

Agua Zarca Sandstone Member. The Agua Zarca Sandstone Member is present south of the Jemez Mountains, west of San Pedro Mountain, and locally in the western foothills of the northern half of the Nacimiento Mountains.

The Agua Zarca consists mainly of cross-stratified, quartzose sandstone with minor amounts of conglomerate and siltstone. The sandstone is distinctly mottled and displays shades of red, purple, yellow, and gray. It is generally coarse grained, friable; and permeable. Silicified plant remains are common. 
The Agua Zarca ranges in thickness from 15 to $114 \mathrm{ft}$. Its thickness varies considerably, partly because it intertongues extensively with, and is overlain by, the Salitral Shale and the unnamed sandstone member, and partly because it fills scours cut into the underlying Permian strata. In places, the Salitral Shale and unnamed sandstone member are absent and the Agua Zarca is directly overlain by the Poleo Sandstone Lentil. Crossbedding indicates that the paleochannels trend predominantly south to southwest (Stewart and others, 1972). Rock composition, texture, and lateral grain-size variations indicate granitic, metamorphic, and sedimentary rock sources probably from highlands to the north and northeast (Stewart and others, 1972).

Unnamed Sandstone Member. The basal Chinle sandstone in the southern Nacimiento Mountains was informally designated the "sandstone member" by Stewart and others (1972). Wood and Northrop (1946) included this unit in the Agua Zarca; however, Stewart and others (1972) distinguished the two units on the basis of color, grain size, and provenance. The "sandstone member" consists predominantly of light-colored, very fine- to fine-grained, quartzose sandstone with interstratified conglomerate and siltstone lenses. It attains a thickness of $165 \mathrm{ft}$ near San Ysidro. In the middle of the Nacimiento area, the "sandstone member" interfingers with and locally overlies the Agua Zarca and grades laterally into the upper part of the Agua Zarca and lower part of the Salitral Shale.

Cross-strata orientations in the unnamed sandstone member indicate north- to northeast-flowing paleostreams and sediments probably derived from the ancient volcanic Mogollon highlands (Stewart and others, 1972).

Salitral Shale Tongue. The Salitral Shale Tongue is present in the San Pedro and northern Nacimiento Mountains area. It intertongues extensively with the Agua Zarca and unnamed sandstone-member and, in places, separates the overlying Poleo Sandstone Lentil from the Agua Zarca. It is composed mostly of variegated bentonitic claystone and siltstone with minor amounts of very fine- to coarse-grained sandstone. The unit varies in thickness from 0 to $100 \mathrm{ft}$.

Poleo Sandstone Lentil. The Poleo Sandstone Lentil is present north of the Jemez Mountains but thins and pinches out southward. Its lower contact is a surface of erosion displaying local scour-and-fill structure; the upper part of the unit intertongues with the overlying Petrified Forest Member. The Polen Sandstone T,enti.l consists of cross-bedded quartzose sandstone and associated conglomerate, claystone, and siltstone. The sandstone is yellowishgray, fine to medium grained, and well indurated. The conglomerate is dark yellowish-orange and consists of quartz, quartzite, and chert pebbles. The thickness varies considerably ( 0 to $165 \mathrm{ft}$ ); this is in part due to channels cut into underlying units and in part due to extensive intertonguing with the overlying Petrified Forest Member. A southern source area, probably the Mogullon highlands, is suggested by paleostream studies (Stewart and others, 1972). 
Petrified Forest Member. The Petrified Forest Member is present north of the Jemez Mountains and in the San Pedro and Nacimiento Mountains area. It is composed of interfingering beds of roughly equal proportions of variegated bentonitic claystone and clayey sandstone and of minor ( $<20$ percent), crossstratified, locally conglomeratic sandstone (Stewart and others, 1972).

EVIDENCE OF URANIUM FAVORABILITY

\section{GENERAL}

Uranium favorability criteria are amply reported in the literature and are summarized by Grutt (1972) and Fischer (1974). Regional and local criteria include host-rock provenance; tuff content of associated rocks; hostrock types; regional transmissivity of permeable beds and unconformities; differential permeability due to various clay contents of sandstone and by interfingering sandstone and mudstone; low dips; host-rock depositional environments; and reductants, notably carbonaceous material. Fluvial, quartzose, feldspathic to arkosic, medium- to coarse-grained, poorly sorted sandstones $>20 \mathrm{ft}$ thick that contain carbonaceous material constitute potential host rocks.

\section{URANIUM SOURCE ROCKS}

Although the question of uranium source remains unanswered, the spatial association of many deposits with uraniferous granite and tuffacenus heds has stimulated speculation that uranium may have been derived by leaching from these rocks. The general favorability of the project area is enhanced by the presence of the Bandelier Tuff (average uranium content about 9 ppm; Table 1), the Precambrian granite (average uranium content about $4 \mathrm{ppm}$ ), and tuffaceous beds in the Chinle Formation. Moreover, possible host-rock lithologies indicate granitic provenance (possible uranium source) in some cases.

\section{TRANSMISSIVITY}

Sandstone units in the Madera, Cutler, and Chinle are medium to coarse grained and conglomeratic; some are thick (>20 ft) and laterally continuous; their transmissivity is probably high. The Chinle is bounded at the base and top by regional unconformities. The channel-fill facies of unconformities provide access to migrating solutions. 
KNOWN URANIUM DEPOSITS

\section{Madera Limestone}

The two known copper-uranium deposits in the Madera Limestone (P1. 3) are $12 \mathrm{mi}$ apart and are unrelated to each other. Both are near faults that intersect deposits in the overlying Cutler Formation. Both deposits are in the upper arkose member in 5- to 10-ft-thick beds of arkose near its gradational contact with the overlying Cutler. The deposits are a few inches; thick and a few feet long. Malachite and azurite cement the radioactive sandstone. Uranium was localized by carbonized plant debris and possibly by "dead oil." No uranium minerals have been identified. The average grade is 0.03 percent $\mathrm{eU}_{3} \mathrm{O}_{8}$ (Table 1 ). No ore has been shipped.

The favorability of the upper arkose member is poor because there are only two low-grade deposits that are apparently fault-related to the overlying Cutler deposits, only 5 percent of the member is permeable arkose, and it has a marginal marine depositional environment.

\section{Cutler Formation}

The 18 known copper-uranium deposits in the Cutler Formation are concentrated in three clusters: 6 south of Gallina (Brown, 1955), 5 west of Coyote (Baltz, 1955), and 7 at Jarosa (Baltz, 1955) [P1. 3]. Each cluster represents spotly mineralization over an area about $3 \mathrm{mi}$ long $\mathrm{x} 1 \mathrm{mi}$ wide. All the deposits are at the base of the formation near the gradational contact with the underlying Madera Limestone. This contrasts with the other known Colorado Cutler deposits that occur near the Permian-Triassic unconforinity and that are related to mineralization of the overiying Chinle Formation (Wood, 1968).

The uranium deposits occur in bleached zones a few feet thick and a few tens of feet long in 35- to 40-ft-thick arkose beds. They range, in size from pods a few inches thick to lenses a few feet thick. The uranium is localized by carbonized plant debris. The secondary minerals, carnotite and andersonite, have been identified (Table 1) and are associated with malachite, azurite, limonite, hematite, and selenite. The deposits average 0.1 percent $\mathrm{U}_{3} \mathrm{O}_{8}$ (Table 1 ). A total of 67 tons averaging 0.12 percent $\mathrm{U}_{3} \mathrm{O}_{8}$, 0.14 percent $\mathrm{V}_{2} \mathrm{O}_{5}$, and 14.0 percent $\mathrm{CaCO}_{3}$ was shipped from $120 \mathrm{ft}$ of drifts and cross cuts at the R:2d Bird adit and the rim cut at the Hillfoot No. 1 . Twenty tons, averaging 0.03 percent $\mathrm{U}_{3} \mathrm{O}_{8}$, was shipped from a 100 -by-300-ft open pit on the Corral No. $3 \mathrm{claim}$ and four tons, averaging 0.07 percent, was shipped from a small cut on the Whiteflo No. 1 claim (Chenoweth, 1972, p. 9).

The favorability of the Cutler is good because: it has 18 known deposits that cluster in three discrete belts that have produced 67 tons of ore; it contains locally abundant carbonized plant debris; it commonly contains bleached lenses in the red-bed sequence where copper sulfides occur; and it has an average sandstone thickness of $40 \mathrm{ft}$ and has a sandstone/shale ratio of $1: 1$. 


\section{Chinle Formation}

There are three known, apparently unrelated uranium deposits 4 to $12 \mathrm{mi}$ apart in the Chinle Formation (PI. 3); all three are at the base of the Agua Zarca Member near the Permian-Triassic unconformity (Wood, 1968). Radioactivity is concentrated in 1-in. - to l-ft-thick sandstone concretions that are enclosed in green mudstone beds. These concretions are limonite cemented, but no uranium minerals have been identified. They average 0.05 percent $\mathrm{U}_{3} \mathrm{O}_{8}$ (Table 1 ), but no ore production is known.

No deposits are known in the Poleo Sandstone Lentil, the unnamed sandstone member, or the Salitral Shale Tongue in the project area. However, one deposit occurs in the Petrified Forest Member outside of the study area.

The favorability of the Agua Zarca Sandstone Member is fair to good because it has a close granitic source, its deposits are near the PermianTriassic unconformity, its sandstone beds average $30 \mathrm{ft}$ in thickness, and its grain size is medium to conglomeratic; however, it contains only three known deposits and has only minor carbonized plant debris.

The favorability of the Poleo Sandstone Member is poor to fair because of the paucity of carbonized plant debris, no known deposits, a fine to medium grain size, a distant volcanic source, and an average sandstone thickness of $20 \mathrm{ft}$.

The favorability of the unnamed sandstone member is also poor to fair because of no known deposits, no observed reductant, a very fine to fine grain size, an average sandstone thickness of $10 \mathrm{ft}$, a distant volcanic source, and a limited areal extent. .

In addition, both the Cutler Formation and the Agua Zarca Sandstone Member of the Chinle Formation may be more favorable to the north in the Chama Basin. There, they are closer to their sources in the ancestral southern Uncompahgre uplift and are presumably thicker bedded, coarser grained, and more permeable. To the south, away from the source, the Cutler becomes progressively thinner bedded and finer grained until, at lat $36^{\circ} \mathrm{N}$., the formations correlative with the Cutler appear and the Agua Zarca Sandstone Member becomes more quartzose and grades into the unnamed sandstone member.

\section{RESULTS}

Chemical uranium was determined for all rock samples (Table 1). In addition, equivalent uranium was determined for Bandelier Tuff and Precambrian granite samples. Equivalent $\mathrm{U}_{3} \mathrm{O}_{8}$ to chemical $\mathrm{U}_{3} \mathrm{O}_{8}$ ratios generally range from one to two, which indicates that the uranium is essentially in equilibrium in these rocks. Uranium contents of ground waters circulating through the Madera Limestone and Cutler and Chinle Formations generally range from 1 to $7 \mathrm{ppb} \mathrm{U}_{3} \mathrm{O}_{8}$ (Table 2), which is within the range established for natural ground waters (Denson and others, 1956). Higher uranium values (17 to $53 \mathrm{ppb} \mathrm{U}_{3} \mathrm{O}_{8}$ ) were recorded in waters near known uranium deposits. The uranium contents of waters draining the Bandelier Tuff average $1 \mathrm{ppb} . \mathrm{U}_{3} \mathrm{O}_{8}$, which suggests that present-day leaching of uranium from this 
unit is minimal. Uranium contents of ground waters draining Precambrian

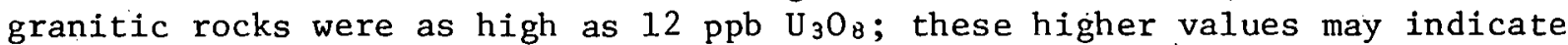
that uranium is being leached from these rocks.

Ás a result of petrographic studies, sedimentary host rocks and possible uranium source rocks were classified (Table 1 ). X-ray diffraction analysis was used in uranium and clay mineral identification. Scanning electron microscope analyses were employed in an attempt to detect authigenic clay minerals in uraniferous samples for possible rubidium-strontium age determinations; however, no authigenic clays were found.

\section{CONCLUSIONS}

The Cutler Formation and the Agua Zarca Member of the Chinle Formation are the units in the study area that have some uranium favorability. Steep dips and deep erosion may have aided the introduction of oxidizing solutions which may have caused remobilization and removal of uranium, consequently lessening the favorability of these units. 


\section{BIBLIOGRAPHY}

Allison, J. W., 1954, Airborne anomalies 6 through 12: U.S. Atomic Energy Comm., Preliminary Recon. Repts. ED: R-414 through 420, Open-File Repts.

Baars, D. L., 1962, Permian system of Colorado Plateau: Am. Assoc. Petroleum Geologists Bull., v. 46, p. 149-218.

1974, Permian rocks of north-central New Mexico, in New Mexico Geo1. Soc. ' Guidebook, 25th Field Conf., North-Central New Mexico: p. 167-169.

Baltz, E. H., 1955, A reconnaissance for uranium in parts of New Mexico and Colorado, 1954: U.S. Geol. Survey TEM-929, issued by the U.S. Atomic Energy Commission, Tech. Inf. Service, Oak Ridge, Tenn., 15 p.

Brassfield, J. C., 1956, Preliminary report on uranium possibilities of the Jemez Indian Reservation and Jemez Pueblo Grant, Sandoval County, New Mexico: U.S. Atomic Energy Comm., TM-82, Open-File Rept., 8 p.

Brown, H. G., III, 1955, Uranium deposits of the Vegitas cluster, Rio Arriba and Sandoval Counties, New Mexico: U.S. Atomic Energy Comm., RME-84, Open-File Rept., 14 p.

Chenoweth, W. L., 1972, Uranium occurrences of the Nacimiento region, Sandoval and Rio Arriba Counties, New Mexico: U.S. Atomic Energy Comm., TM-189, Open-File Rept., 15 p.

1974, Uranium occurrences of the Nacimiento-Jemez region, Sandoval and Rio Arriba Counties, New Mexico, in New Mexico Geol. Soc. Guidebook, 25th Field Conf., North-Central New Mexico: p. 3n9-31.3.

Cross, W., and Howe, E., 1905, Description of Silverton quadrangle: U.S. Geol. Survey Geol. Atlas, Folio N120.

Denson, N. M., Zeller, H. D., and Stephens, J. C., 1956, Water sampling as a guide for uranium deposits and its use in cvaluating widespread volcanic units as potential source beds for uranium, in Page, T.. R,, Stocking, H. E., and Smith, H. B., comps., Contributions to the geology of uranium and thorium by the United States Geological Survey and Atomic Energy Commission for the United Nations International Conference on Peaceful Uses of Atomic Energy, Geneva, Switzerland 1955: U.S. Geol. Survey Prof. Paper 300, p. 673-675.

Duchene, H. R., 1974, Pennsylvanian rocks of north-central New Mexico, in New Mexico Geol. Soc. Guidebook, 25th Field Conf., North-Central New Mexico: p. 159-162.

Fischer, R. P., 1974, Exploration guides to new uranium districts and belts: Econ. Geology, v. 69, p. 362-376.

Gregory, H. E., 1917, Geology of the Navajo country - A reconnaissance of parts of Arizona, New Mexico, and Utah: U.S. Geol. Survey Prof. Paper 93, p. 161. 


\section{BIBLIOGRAPHY (continued)}

Grutt, E. W., Jr., 1972, Prospecting criteria for sandstone-type uranium deposits, in Bowie, S.H.U., Davis, M., and Ostle, D., eds., Uranium prospecting handbook: London, Inst. Mining and Metallurgy, p. 47-76.

Hilpert, L. S., 1969, Uranium resources of northwestern New Mexico: U.S. Geol. Survey Prof. Paper 603, 166 p.

Keyes, C. R., 1903, Geological sketches of New Mexico: Ores and Metals,.v. 12 , p. 48.

O'Sullivan, R. B., 1974, The Upper Triassic Chinle Formation in north-central New Mexico, in New Mexico Geol. Soc. Guidebook, 25th Field Conf. NorthCentra1 New Mexico: p. 171-174.

Read, C. B., and Wood, G. H., Jr., 1947, Distribution and correlation of Pennsylvanian rocks in Late Paleozoic sedimentary basins of northern New Mexico: Jour. Geology, v. 55, p. 220-236.

Stewart, J. H., Poole, F. G., and Wilson, R. F., 1972, Stratigraphy and origin of the Chinle Formation and related Upper Triassic strata in the Colorado Plateau region: U.S. Geol. Survey Prof. Paper 690, 336 p.

Wood, G. H., and Northrop, S. A., 1946, Geology of Nacimiento Mountains, .San Pedro Mountains and adjacent plateaus in parts of Sandoval and Rio Arriba Counties, New Mexico: U.S. Geol. Survey Oil and Gas Inv. Prelim. Map 57.

Wood, H. B., 1968, Geology and exploitation of uranium deposits in the Lisbon Valley area, Utah, in Ridge, J. B., ed., Ore deposits of the United States 1933 through 1967: Am. Inst. Mining, Metall. and Petroleum Engineers, P. 771-789.

Woodward, L. A., Kaufman, W. H., and Anderson, J. B., 1972a, Nacimiento fault and related structures, northern New Mexico: Geol. Soc. America Bull., v. 83 , p. 2383-2396.

Woodward, L. A., Anderson, J. B., McLelland, D. H., and Kaufman, W. H., 1972b, Geologic map and section of the Cuba quadrangle, New Mexico: New Mexico Bur. Mines and Mineral Resources Geol. Map 25, scale 1:24,000.

Woodward, L. A., Kaufman, W. H., Anderson, J. B., and Reed, R. K., 1973a, Geologic map and sections of the San Pablo quadrangle, New Mexico: New Mexico Bur. Mines and M1neral Resources Geo1. Map 26, scale 1:24,000.

Woodward, L. A., Kaufman, W. H., and Reed, R. K., 1973b, Geologic map and section of the Rancho del Chaparral quadrangle, New Mexico: New Mexico Bur. Mines and Mineral Resources Geol. Map 27, scale 1:24,000.

Woodward, L. A., and Schumacher, 0. L,; 1973c, Geologic map and sections of La Ventana quadrangle, New Mexico: New Mexico Bur. Mines and Mineral Resources Geol. Map 28, scale 1:24,000. 
Woodward, L. A.-, and Martinez, Ruben, 1974a, Geologic map and sections of the Holy Ghost Spring quadrangle, New Mexico: New Mexico Bur. Mines and Mineral Resources Geol. Map 33, scale 1:24,000.

Woodward, L. A., Martinez, Ruben, Duchene, H. R., Schumacher, O. L., and Reed, R. K., 1974b, Precambrian rocks of the southern Sierra Nacimiento, New Mexico, in New Mexico Geol. Soc. Guidebook, 25th Field Conf., NorthCentral New Mexico: p. 95-100.

Woodward, L. A., McLelland, D. H., and Kaufman, W. H., 1974c, Geologic map and sections of the Nacimiento Peak quadrangle, New Mexico: 'New Mexico Bur. Mines and Mineral Resources Geol. Map 32, scale 1:24,000.

Woodward, L. A., and Duchene, H. R., 1974d, Geologic map and sections of the San Miguel Mountain quadrangle, New Mexico: New Mexico Bur. Mines and Mineral Resources Geol. Map 34, scale 1:24,000.

Woodward, L. A., and Ruechilling, R. L., 1976, Geologic map and sections of the San Ysidro quadrangle, New Mexico: New Mexico Bur. Mines and Mineral Resources Geol. Map 37, scale 1:24,000. 


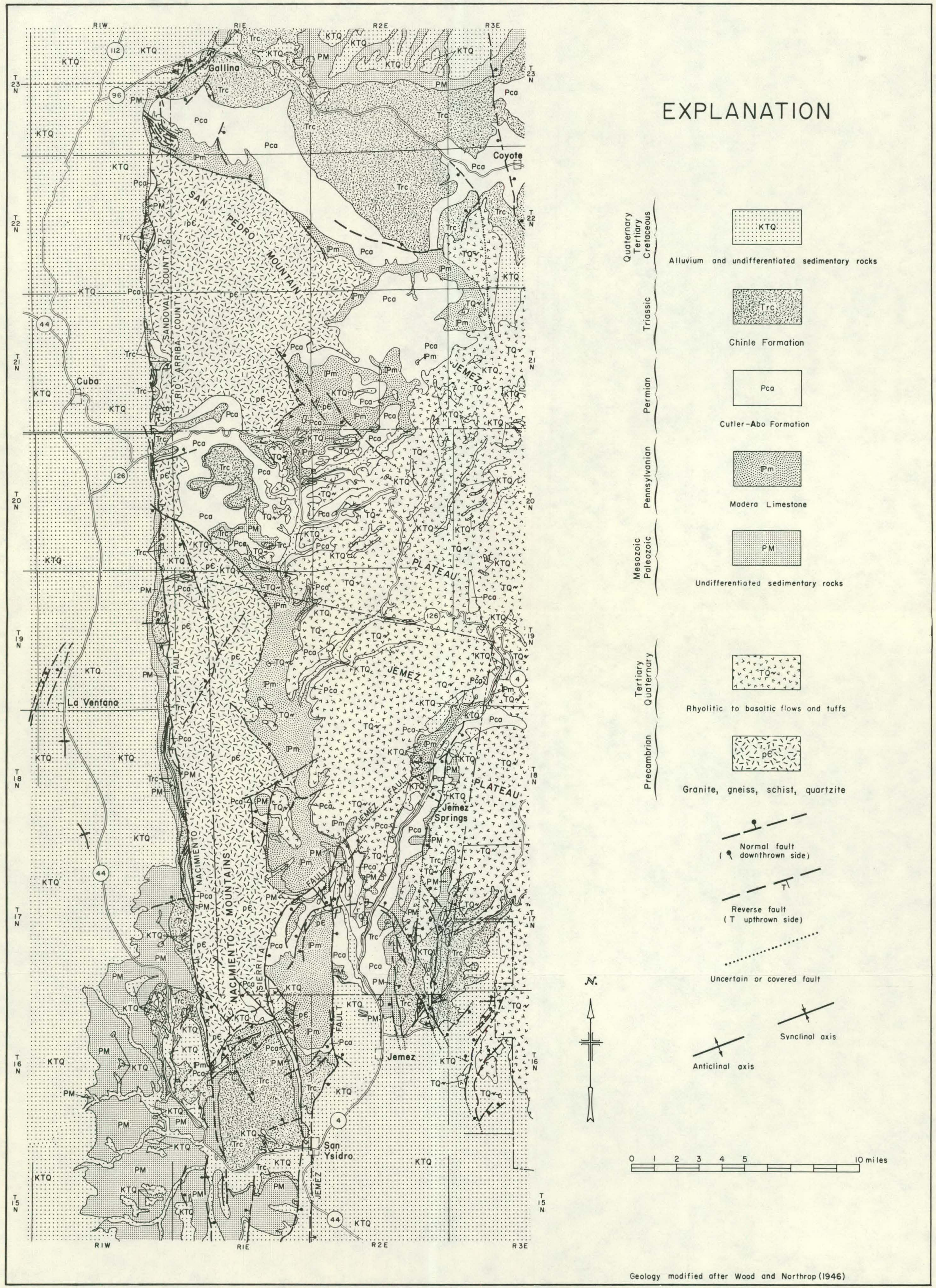

PLATE 1. GEOLOGIC MAP OF THE SIERRA NACIMIENTO - JEMEZ MOUNTAINS AREA 


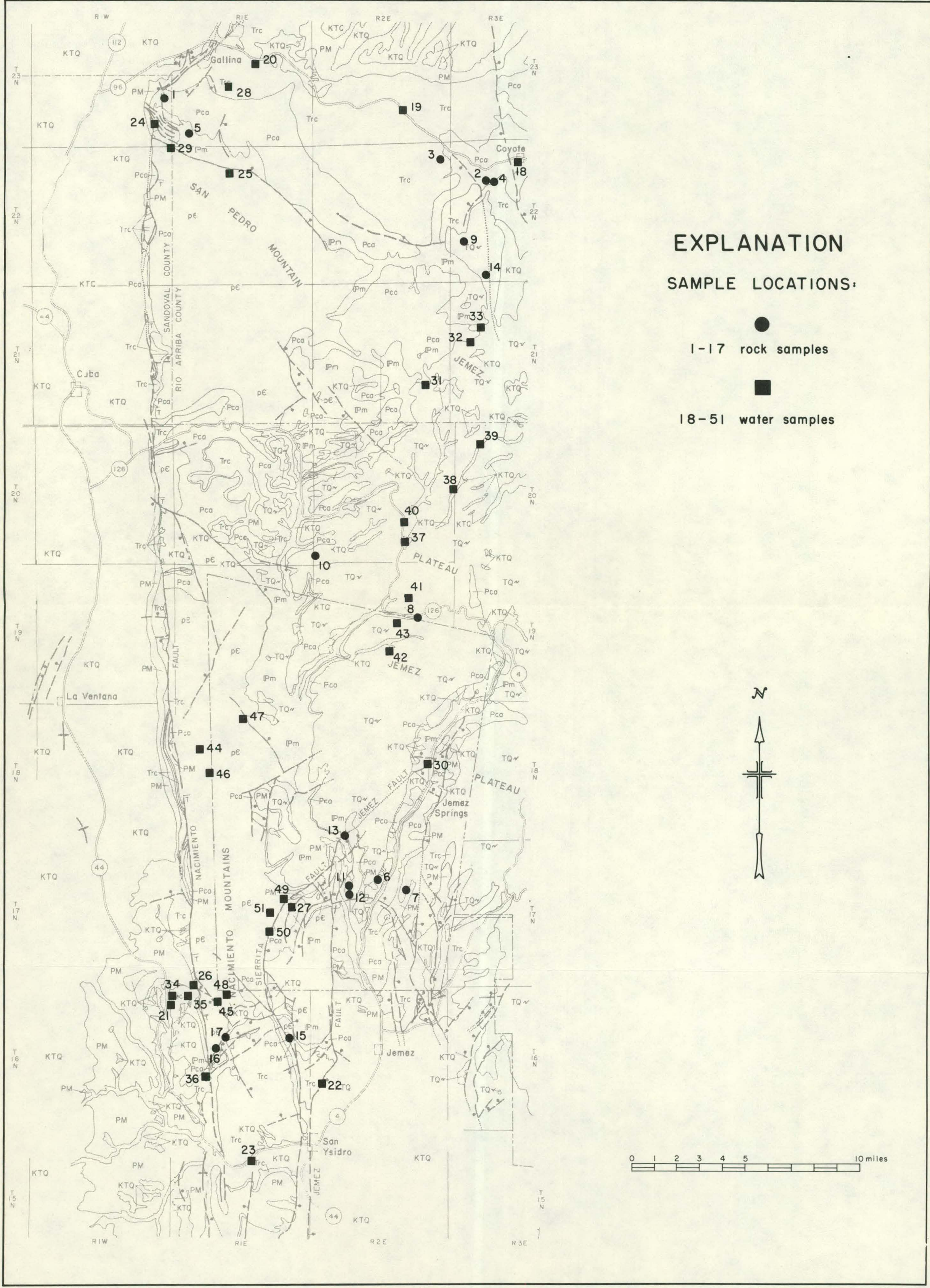

PLATE 2. SAMPLE LOCATIONS 


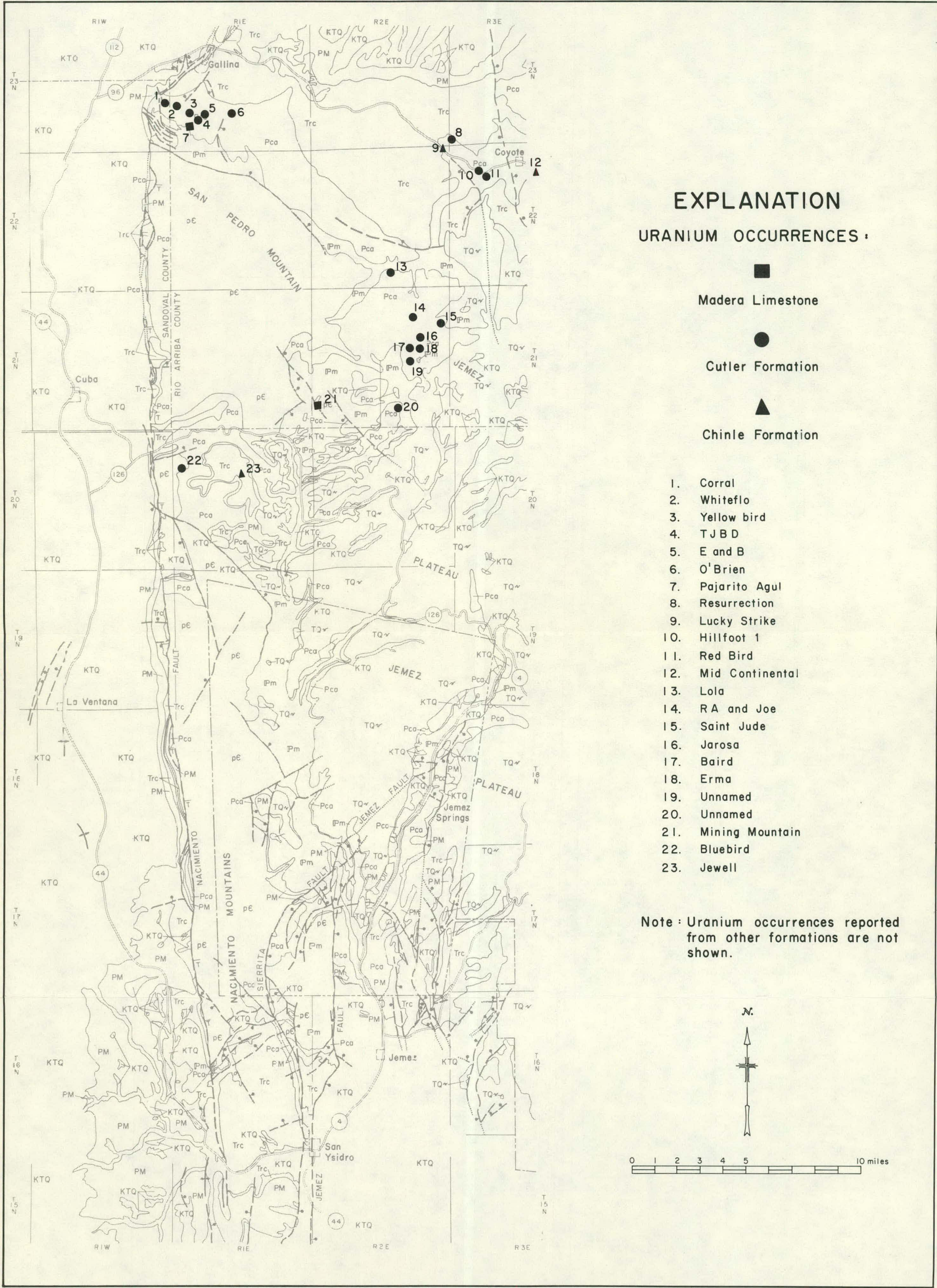

PLATE 3. KNOWN URANIUM OCCURRENCES IN THE MADERA LIMESTONE, CUTLER FORMATION, AND CHINLE FORMATION, SIERRA NACIMIENTO - JEMEZ MOUNTAINS, NEW MEXICO 